\title{
On the Neotropical genus Cybaeodamus (Araneae, Zodariidae, Storeninae)
}

\author{
Arno A. Lise ${ }^{1}$, Ricardo $\mathrm{Ott}^{2}$ \& Everton N. L. Rodrigues ${ }^{3}$ \\ 1. Laboratório de Aracnologia, Museu de Ciências e Tecnologia, Pontifícia Universidade Católica do Rio Grande do Sul, Av. Ipiranga, \\ 6681, Prédio 40, sala 167, 90619-900 Porto Alegre, RS, Brazil. (lisearno@pucrs.br) \\ 2. Museu de Ciências Naturais, Fundação Zoobotânica do Rio Grande do Sul, Rua Dr. Salvador França, 1427, 90690-000 Porto Alegre, RS, \\ Brazil. (rott@fzb.rs.gov.br) \\ 3. Programa de Pós-Graduação em Biologia Animal, Instituto de Biociências, Universidade Federal do Rio Grande do Sul, Av. Bento \\ Gonçalves, 9500, Bloco IV, Prédio 43435, 91501-970 Porto Alegre, RS, Brazil. (enlrodrigues@yahoo.com.br)
}

\begin{abstract}
Four new species of the spider genus Cybaeodamus Mello-Leitão, 1938 are described and illustrated: C. meridionalis sp. nov. from Brazil and Argentina, C. taim sp. nov. from Brazil, Argentina and Uruguay, C. brescoviti sp. nov. and C. tocantins sp. nov. from setentrional region of Brazil. For the species Cybaeodamus enigmaticus (Mello-Leitão, 1939), C. lycosoides (Nicolet, 1849) and C. ornatus Mello-Leitão, 1938, new illustrations based on the examination of the types are presented. The species Cybaeodamus nigrovittatus Mello-Leitão, 1941 which the holotype is an immature specimen, C. pallidus (Mello-Leitão, 1943) which the type was not located, $C$. rastellifer (Mello-Leitão, 1940) and C. scottae Mello-Leitão, 1941, both described upon juvenile specimens, all from Argentina, are considered as species inquirendae.
\end{abstract}

KEYWORDS. Spiders, Zodariidae, Neotropical region, taxonomy.

RESUMO. Sobre o gênero Neotropical Cybaeodamus (Araneae, Zodariidae, Storeninae). Neste trabalho são descritas e ilustradas quatro espécies novas do gênero Cybaeodamus Mello-Leitão, 1938: C. meridionalis sp. nov. do Brasil e Argentina, C. taim sp. nov. do Brasil, Argentina e Uruguai, C. brescoviti sp. nov. e C. tocantins sp. nov. do Brasil setentrional. Para as espécies Cybaeodamus enigmaticus (Mello-Leitão, 1939), C. lycosoides (Nicolet, 1849) e C. ornatus Mello-Leitão, 1938 são apresentadas novas ilustrações a partir do exame do material-tipo. As espécies Cybaeodamus nigrovittatus Mello-Leitão, 1941 cujo holótipo é um indivíduo jovem, $C$. pallidus (Mello-Leitão, 1943) da qual o tipo não foi localizado, C. rastellifer (Mello-Leitão, 1940) e C. scottae Mello-Leitão, 1941, ambas com tipos juvenis, todas da Argentina, são consideradas species inquirendae.

PALAVRAS-CHAVE. Aranhas, Zodariidae, Região Neotropical, taxonomia.

In the revision of the genera of Zodariidae, JocQué (1991) divided the family in six subfamilies that are: Cyriocteinae Jocqué, Lachesaninae Jocqué, Storenomorphinae Simon, Cydrelinae Simon, Zodariinae Simon, and Storeninae Simon. The genus Cybaeodamus Mello-Leitão, 1938 belongs to this last subfamily. This subfamily is diagnosed by JocQué (1991) by its representatives having "metatarsal ventral hair tufts with hollow chisel-shaped hairs, hinged hairs are few, and restricted to the dorsal side of the leg segments, except in Cybaeodamus where they are numerous".

Cybaeodamus was proposed by Mello-Leitão (1938) to include $C$. ornatus, described from Argentina. According to JocQué (1991), the males of Cybaeodamus "are recognized by the palps with two tegular apophysis (distal and lateral) of which the distal one is large and complex; females have a large epigynum with a strongly sclerotized area on both sides; the chelicerae are densely haired in both sexes".

Up to now Cybaeodamus comprises seven exclusively South American species (Platnick, 2007): $C$. lycosoides (Nicolet, 1849) from Chile; C. ornatus MelloLeitão, 1938 from Argentina, Uruguay and Peru; $C$. enigmaticus (Mello-Leitão, 1939), C. nigrovittatus MelloLeitão, 1941, C. pallidus (Mello-Leitão, 1943), C. rastellifer (Mello-Leitão, 1940) and C. scottae MelloLeitão, 1941 from Argentina.
In this paper all know species of the genus are revised based on the examination of the types and four new species are described, two from setentrional region of Brazil and two from meridional South America, comprising the south of Brazil, Uruguay and north of Argentina and new illustrations of the species are presented.

\section{MATERIAL AND METHODS}

The material studied are deposited in the following institutions: FCE-AR, Facultad de Ciencias, Entomología, Marindia, Canelones (Miguel Simó); IBSP, Instituto Butantan, São Paulo (Antonio Domingos Brescovit); LACB, Laboratório de Aracnologia do Instituto de Ciências Biológicas da Universidade Federal de Minas Gerais, Belo Horizonte (Mário De Maria); MACN, Museo Argentino de Ciencias Naturales "Bernardino Rivadavia", Buenos Aires (Cristina Luisa Scioscia); MCN, Museu de Ciências Naturais da Fundação Zoobotânica do Rio Grande do Sul, Porto Alegre (Erica Helena Buckup); MCTP, Museu de Ciências e Tecnologia da Pontifícia Universidade Católica do Rio Grande do Sul, Porto Alegre (Arno Antonio Lise); MLP, Museu de La Plata, La Plata (Luis Alberto Pereira); MNHN, Museum National d'Histoire Naturelle, Paris (Christine Rollard) and MZSP, Museu de Zoologia da Universidade de São Paulo, São Paulo (Ricardo Pinto-da-Rocha). 
Descriptions and nomenclature of the male palpus follow JocQuÉ (1991). The study of internal reproductive structures of female epigynum was performed immersing it in lactic acid or in clove oil. All measurements are in millimeters. The scanning electron micrographs (SEM) were made using a electronic microscope of the Centro de Microscopia e Microanálises of Pontifícia Universidade Católica do Rio Grande do Sul (PUCRS) .

\section{Cybaeodamus Mello-Leitão, 1938}

Cybaeodamus Mello-Leitão, 1938:93; 1941:107; Rотн, 1965:290; LEHTINEN, 1967:226.

Hyltoniella Mello-Leitão, 1940:29 (type species Hyltoniella birabeni); JocQué, 1991:49. Hyltoniella synonimized by JocQUé, 1991:49.

Valcheta Mello-Leitão, 1940:20 (type species Valcheta rastellifera); Rотн, 1965:291 (transferred to Zodariidae); LEHTINEN, 1967:274; JoCQuÉ, 1991:49. Valcheta synonimized by JocQuÉ, 1991:49.

\section{Cybaeodamus meridionalis sp. nov.}

(Figs. 1-20, 68)

Types. Holotype $\sigma^{7}$, BRAZIL, Rio Grande do Sul: Xangrilá, 09.XI.1986, A. A. Lise col. (MCN 16013). Paratypes: $0^{7}$, Portão, 21.XI.1993, G. Pontes col. (MCTP 4619); 39, Xangrilá, 23.XI.1985, A. A. Lise col. (MCN 16074); ơ, 2o, Xangrilá, 17.I.1987, A. A. Lise col. (MCN 16645); đ̛, Xangrilá, 21.I.1989, A. A. Lise col. (MCN 18141); + , Viamão (Parque Estadual de Itapuã), 17.XII.2003, A. C. K. Ferreira col. (MACN 10755); ㅇ, Viamão, 10.V.1990, L. A. Santos col. (MCTP 1274); ơ, Porto Alegre, 22.I.1989, A. A. Lise col. (MCN 18142); O’, Porto Alegre (Jardim Botânico), 20.XI.1999, A. B. Bonaldo col. (MCN 31618). Distrito Federal: ơ, Brasília (Área da Marinha), 29-31.X.1999, G. G. Montingelli col. (IBSP 26543). Mato Grosso do Sul: + , Corumbá (Passo da Lontra, Capões), VII.1999, A. D. Brescovit col. (IBSP 23934).

Etymology. The name in apposition reffers to the South American distribution.

Diagnosis. Males of $C$. meridionalis sp. nov. differ from other species of the genus by the presence of a translucent lamella on the base of the tegulum and by the larger distance between the apex of the tegular distal apophysis and the median tegular apophysis (Figs. 2-5, 8). Females differ from other species of the genus by the presence of a patch of serrate setae on the ventral face of abdomen (Figs. 13, 14) and by the shorter length of the copulatory ducts (Figs. 7, 10).

Description. Male (holotype). Total length 8.20. Carapace 4.10 long, 2.80 wide, 1.50 height. Sternum 1.80 long, 1.50 wide. Carapace oval, convex, narrower on the anterior region (Fig. 1). Cephalic region higher. General color dark chestnut almost black. Fovea longitudinal, short, narrow and little deep. Radial furrows of thorax demarcate only by the presence of double row of yellow macrosetae. Chelicerae dark chestnut, densely covered with short spatulate setae. Promargin of the fang furrow with two short teeth, claw short and thick. Labium triangular with rounded apex, chestnut. Endites triangular, convergent (Fig. 11). Sternum reddish chestnut, convex, densely clothed with setae. Anterior and posterior row of eyes procurved. Anterior eye row 0.68 wide, posterior 1.00. Leg formula 4.1.3.2. Measurements I/II/III/IV: femur $2.40 / 2.10 / 2.05 / 2.60$; patella $1.10 / 1.10 / 1.10 / 1.10$; tibia $1.75 /$ 1.40/1.25/1.85; metatarsus 1.80/1.55/1.80/2.75; tarsus 1.45/ 1.25/1.25/1.45. Total 8.50/7.40/7.45/9.75. Coxae and femura brown-olivaceous, remaining articles chestnut. On the dorsal face of patellae and tibiae there are setae disposed on longitudinal rows, remaining articles densely setaceous. Abdomen: 4.05 long, 2.50 wide, 2.50 height Dorsum dark chestnut, almost black on the laterals, permitting to see the whitish yellow bottom. Venter same color of dorsum with scavated circular spots disposed on two longitudinal lines. Epigastric plates yellow. Anterior margin of the epigastric furrow with a chestnut more sclerotinized edge. Palpus with the lateral apophysis hook shaped. Distal tegular apophysis hook shaped with a longitudinal groove where the embolus fit. Tibial apophysis well developed (Figs. 2, 3).

Female (paratype, MCN 16074). Total length 9.00. Carapace 4.25 long, 2.75 wide, 1.30 height. Sternum 1.75 long, 1.55 wide. Carapace (Fig. 12) dark chestnut, region around fovea lighter. Chelicerae dark chestnut, densely covered with setae on the anterior face with two small teeth on the anterior margin of the fang furrow. Labium with rounded apex, setaceous. Sternum chestnut, cordiform, densely setaceous. Anterior and posterior row of eyes procurved. Leg (Figs. 17-20) formula 4.1.2.3. Measurements: I/II/III/IV: femur 2.30/2.00/1.75/2.40; patella 1.15/1.10/1.05/1.20; tibia 1.55/1.25/1.15/1.70; metatarsus 1.30/1.10/1.35/2.50; tarsus 1.00/1.00/1.00/1.25. Total 7.30/6.45/6.30/9.05. All articles reddish chestnut, the femura darker. Abdomen 5.25 long, 3.50 wide, 2.95 height, densely covered with microsetae. Color of dorsum black with two anterior spots, one each side forming a "V" and some yellow spots of variable size. Laterals and venter dark chestnut almost black with many small spots longitudinally disposed. Spinnerets (Figs. 15, 16). Epigynum (Figs. 6, 9) with a median deep depression and above it there are two narrow and deep excavations, one each side where are the fecundation openings. The spermatecae are spherical and between them there are the fecundation ducts (Figs. 7, 10).

Variation. Males (15). Total length: 8.00-10.00; carapace: 4.10-5.20; femur I: 2.80-3.20. Females (10). Total length: 9.40-12.00; carapace: 4.50-5.80; femur I: 2.70-3.00.

Distribution. Brazil (Distrito Federal, Mato Grosso, Mato Grosso do Sul, Minas Gerais, São Paulo, Santa Catarina and Rio Grande do Sul) and Argentina (Jujuy and Salta).

Other material examined. ARGENTINA. Jujuy: Banda de Los Perales, O’, + 13.XII.1950, M. Birabén col. (MLP 17503). Salta: Anta (between del Rei and Lumbada), $\odot, ~ 17 . X I .1966$, M. E. Galiano col. (MACN 10722). BRAZIL. Mato Grosso: Chapada dos Guimarães, 9O', 20-29.XI.2000, C. Strüssman col. (MCTP 11540). Minas Gerais: Belo Horizonte (B. Pampulha), o ${ }^{7},+$, A Campagnani col. (LACB 1321). São Paulo: São Carlos, O’, 20.VII.1982, J. Henrique col. (MCN 24930). Santa Catarina: Florianópolis (Campeche), O. I.2000, A. D. Brescovit col. (IBSP 27553). Rio Grande do Sul: Xangrilá, 30', 5, 18.XI.199019.II.1999, A. A. Lise col. (MCTP 1082, 2905, 2973, 3940, 9560 10484); Canoas (Capão do Corvo), + , 23.IV.1966, A. A. Lise col. (MCN 190); Viamão (Parque Estadual de Itapuã), 230', 89, 18.XI.2003-10.II.2004, A. C. K. Ferreira col. (MCTP 1641816440); , 10.V.1990, L. A. Santos col. (MCTP 1274); Passo do Vigário, +, 03.III.1993, R. Balestrin col. (MCTP 3031); Porto Alegre (Morro Santana), , 05.IV.1968, A. A. Lise col. (MCN 1937); ㅇ, 15.II.1989, A. D. Brescovit (MCN 18325); Porto Alegre (Jardim Botânico), O’, 20.XI.1990, A. D. Brescovit col. (MCN 20106); Porto Alegre (Jardim Botânico), O’, 26.XI.1992, A. B Bonaldo col. (MCN 22550). 

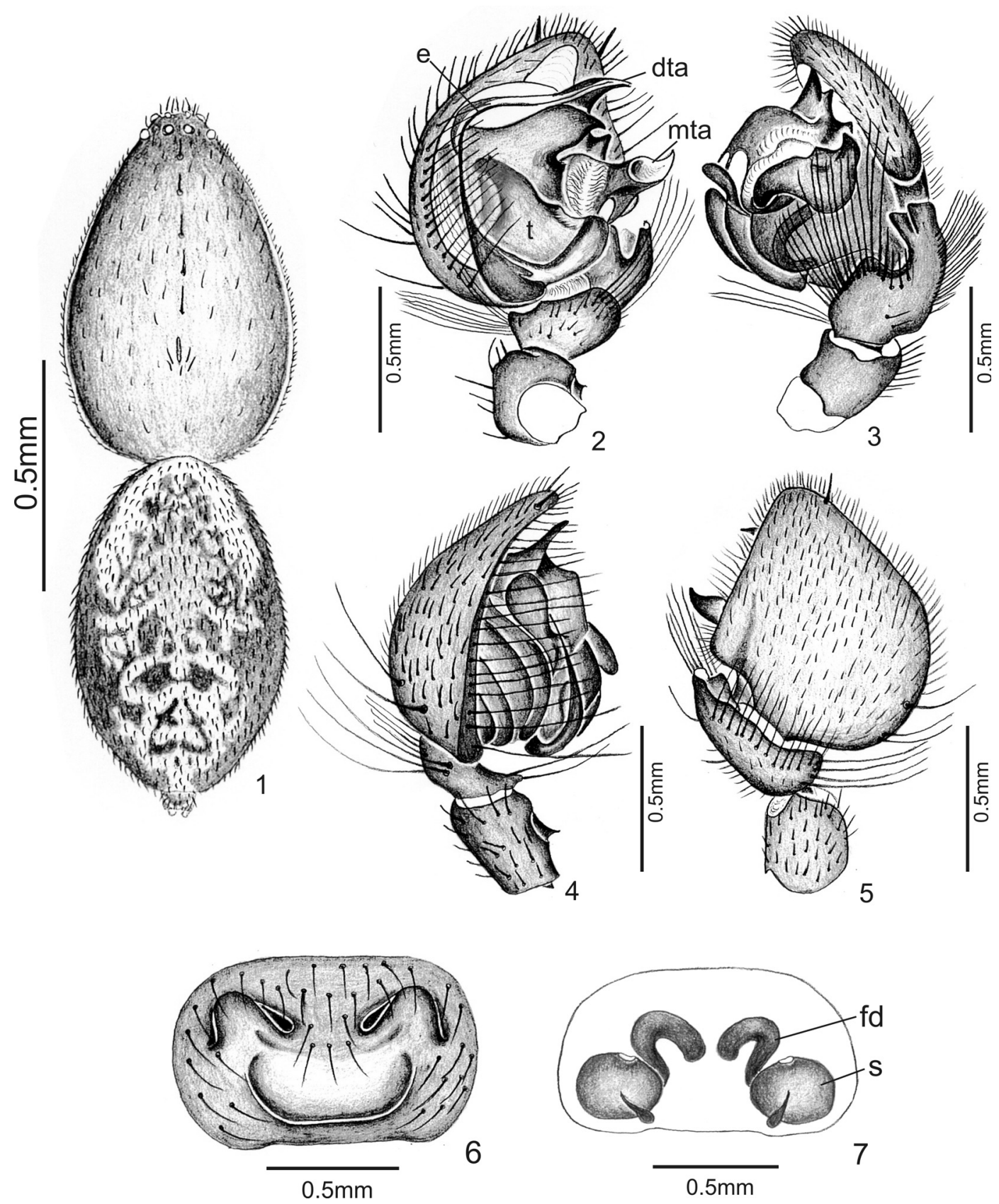

Figures 1-7. Cybaeodamus meridionalis sp. nov.: 1, male body, dorsal view; 2-5, male palpus: 2, ventral view; 3, retrolateral view; 4, prolateral view; 5, dorsal view; 6, 7, female epigynum: 6, ventral view; 7, dorsal view, cleared (dta, distal tegular apophysis; e, embolus; fd, fecundation duct; mta, median tegular apophysis; s, spermatecae; t, tegulum).

\section{Cybaeodamus taim sp. nov.}

(Figs. 21-36, 68)

Types. Holotype ơ, BRAZIL, Rio Grande do Sul: Rio Grande (Estação Ecológica do Taim), 02.XII.1986, A. D. Brescovit col. (MCN 16548). Paratypes: ㅇ, Viamão (Itapuã), 19.I.1977, M. L. Tavares col. (MCN 5047); ơ,, , Viamão (Parque Estadual de Itapuã), 29.VIII.2003, A. C. K. Ferreira col. (MACN 10756); $5 \sigma^{2}$, same locality and date of the holotype, A. D. Brescovit col. (MCN 16548); O', same locality of the holotype, 02.XII.1986, E. H. Buckup col. (MCN 16301).

Etymology. The specific name is a noun in apposition to the genus name, taken from the type locality.
Diagnosis. Males of $C$. taim sp. nov. differ from the males of the other species of the genus by the presence of an excavation on the median posterior portion of the sternum (Fig. 25) and by the presence of setiferous basal tubercles on the coxae (III-IV), by the tibial apophysis of the palpus with a small hook shape projection (Fig. 24); females differs from the ones of the other species by the epigynum having long copulatory ducts close to each other on the portion near the spermatecae (Figs. 27, 28).

Description. Male (holotype). Total length 9.70. Carapace 5.50 long, 3.90 wide, 2.13 height. Sternum 2.46 
long, 1.95 wide. Carapace suboval, narrower on the anterior portion, cephalic region higher (Figs. 21, 26). General color light fulvous, glabrous with only one median longitudinal row of setae that extends from the ocular area to fovea, this longitudinal and narrow. Chelicerae fulvous, densely setaceous (Fig. 26). Endites triangular (Fig. 25), yellow with apical black scopula covered with long and thick setae except on the central area which is glabrous. Labium fulvous, setaceous with the basal ectal margins darker. Sternum dark fulvous with a central anterior yellow area densely setaceous, with one deep excavation each side, on the level of coxa III (Fig. 25). Ocular area densely covered with thick black setae. Anterior and posterior eye row procurved. Legs formula 4.1.3.2. Measurements I/II/III/IV: femur 3.75/3.60/3.25/4.10; patella 1.70/1.60/1.60/1.70; tibia 2.63/2.05/1.75/2.50;
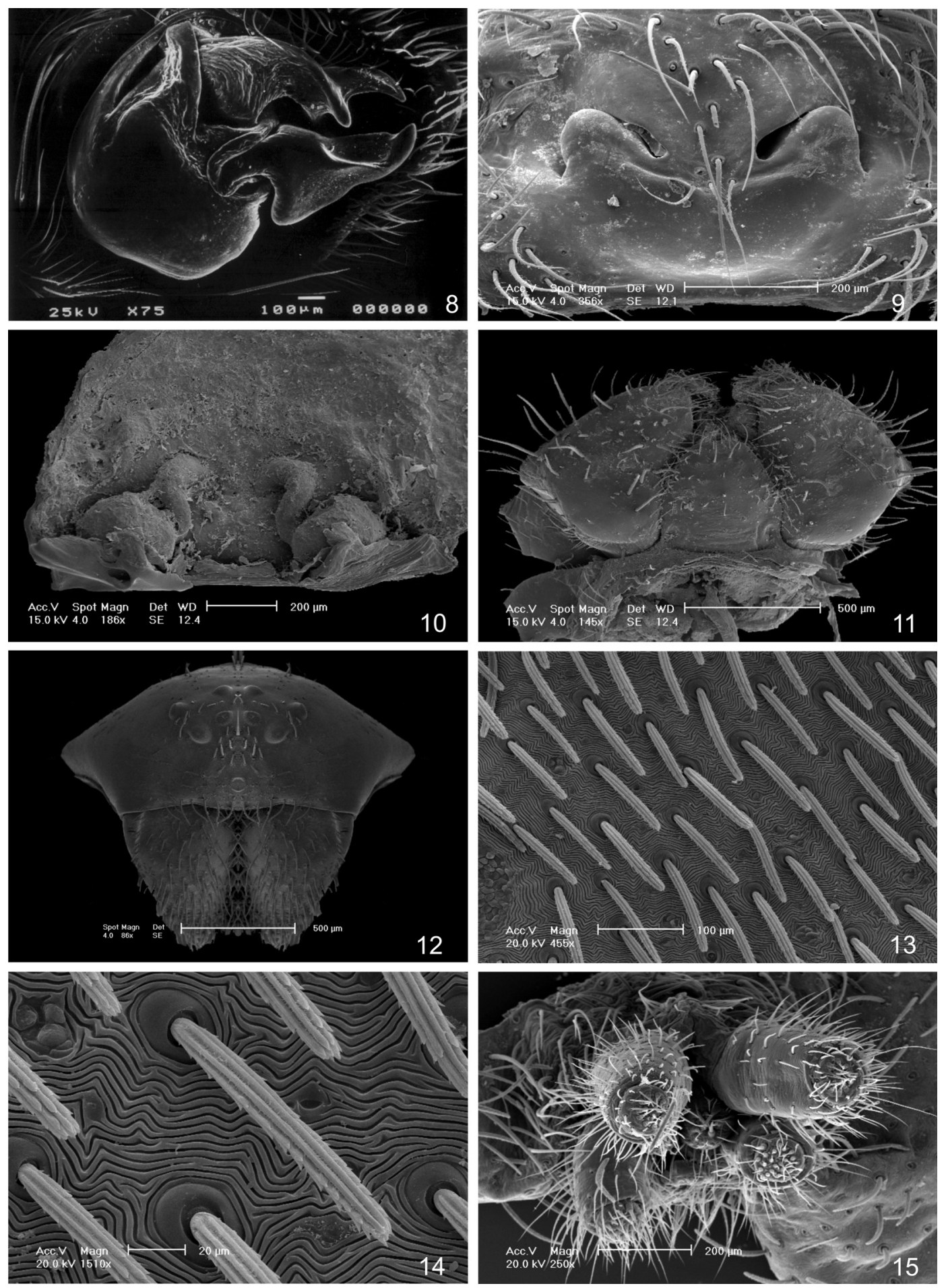

Figures 8-15. Cybaeodamus meridionalis sp. nov.: 8, male palpus, ventral; 9, 10, female epigynum: 9, ventral view; 10, dorsal view; 11, endites and labium; 12, carapace and chelicerae, frontal view; 13, patch setae of the ventral face of abdomen; 14, detail of setae; 15, female spinnerets. 
metatarsus 2.85/2.00/2.80/3.95; tarsus 1.75/1.60/1.50/1.85. Total 12.68/10.85/10.90/14.12. Legs light fulvous, femur lighter on the ventral and lateral faces. Coxae III and IV with a rhombus setiferous basal tubercle, the more developed in coxa III (Fig. 25). Legs III and IV spiny. Abdomen (Figs. 21, 35), 4.50 long, 3.30 wide, 2.95 height. Dorsum guanine white spotted with dark reddish chestnut (Fig. 21). Venter same color of dorsum but the guanine spots less conspicuous. Laterals with rows of dark chestnut spots. Ventral face with a patch of many lying granulated setae directed backward (Fig. 35). Lateral and dorsal faces coated with no modified setae. Spinnerets light fulvous. Tibial apophysis of palpus with a small hook and lateral tegular apophysis lamelar (Figs. 22-24, 29-32).

Female (paratype, MCN 5047). Total lenght 8.60. Carapace 8.60 long, 2.80 wide, 1.25 height. Sternum 2.14 long, 1.58 wide. Carapace suboval narrower anteriorly. General color light fulvous, glabrous with a single longitudinal median row of setae that extend from the ocular area to the fovea, this longitudinal and narrow.
Chelicerae dark fulvous very setaceous. Endites light fulvous. Labium dark fulvous. Sternum scutiform very convex, all covered with setae, fulvous, without the excavations that occurs in the male. Ocular area very setaceous. Anterior and posterior eyes row procurved. Legs formula 4.1.2.3. Measurements I/II/III/IV: femur 2.63/ 2.40/2.23/2.96; patella 1.31/1.25/1.15/1.35; tibia $1.81 / 1.48 /$ 1.21/1.81; metatarsus 1.64/1.58/1.86/2.80; tarsus 1.16/1.15/ 1.11/1.31. Total 8.55/7.86/7.56/10.23. Legs fulvous III and IV spiny. Abdomen 4.80 long, 3.30 wide, 2.63 height. Dorsum as on the male. Venter same color of dorsum but the guanine spots less conspicuous. Laterals with rows of dark chestnut spots. All faces of abdomen coated with setae (Fig. 36). Spinnerets light fulvous. Epigynum (Figs. 27, 33) with well developed spermatecae (Figs. 28, 34).

Variation. Males (5). Total length: 9.50-10.80; carapace: 5.00-6.00; femur I: 3.50-4.15.

Distribution. South of Brazil (Rio Grande do Sul), Uruguay (Canelones) and Argentina (Misiones, Mendoza, Río Negro, Neuquén, Chubut and Santa Cruz).
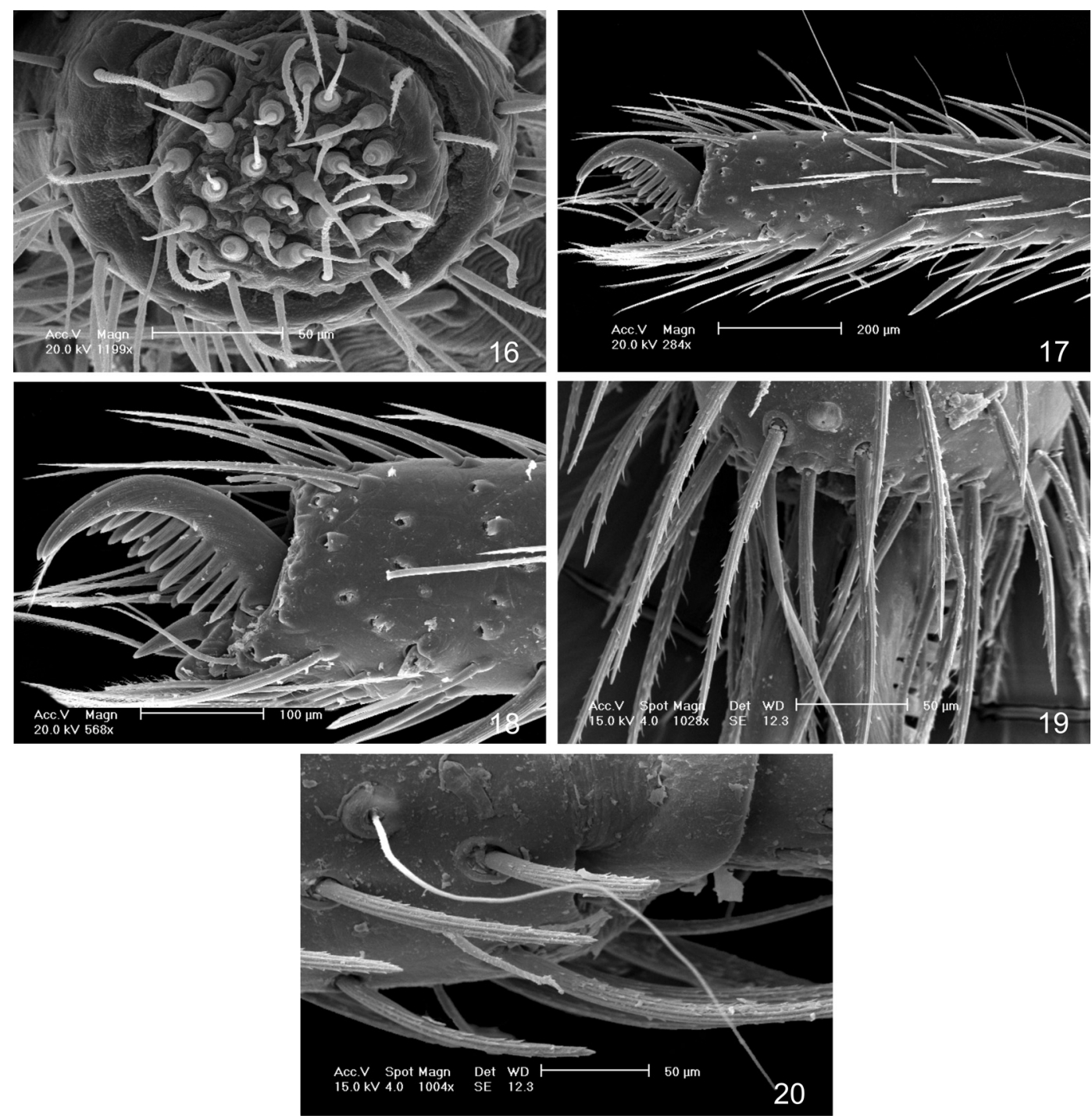

Figures 16-20. Cybaeodamus meridionalis sp. nov., female: 16, anterior lateral spinneret, detail; 17-20, leg I: 17, tarsus; 18, tarsus, detail; 19, tarsal organ; 20, trichobothrium on metatarsus. 

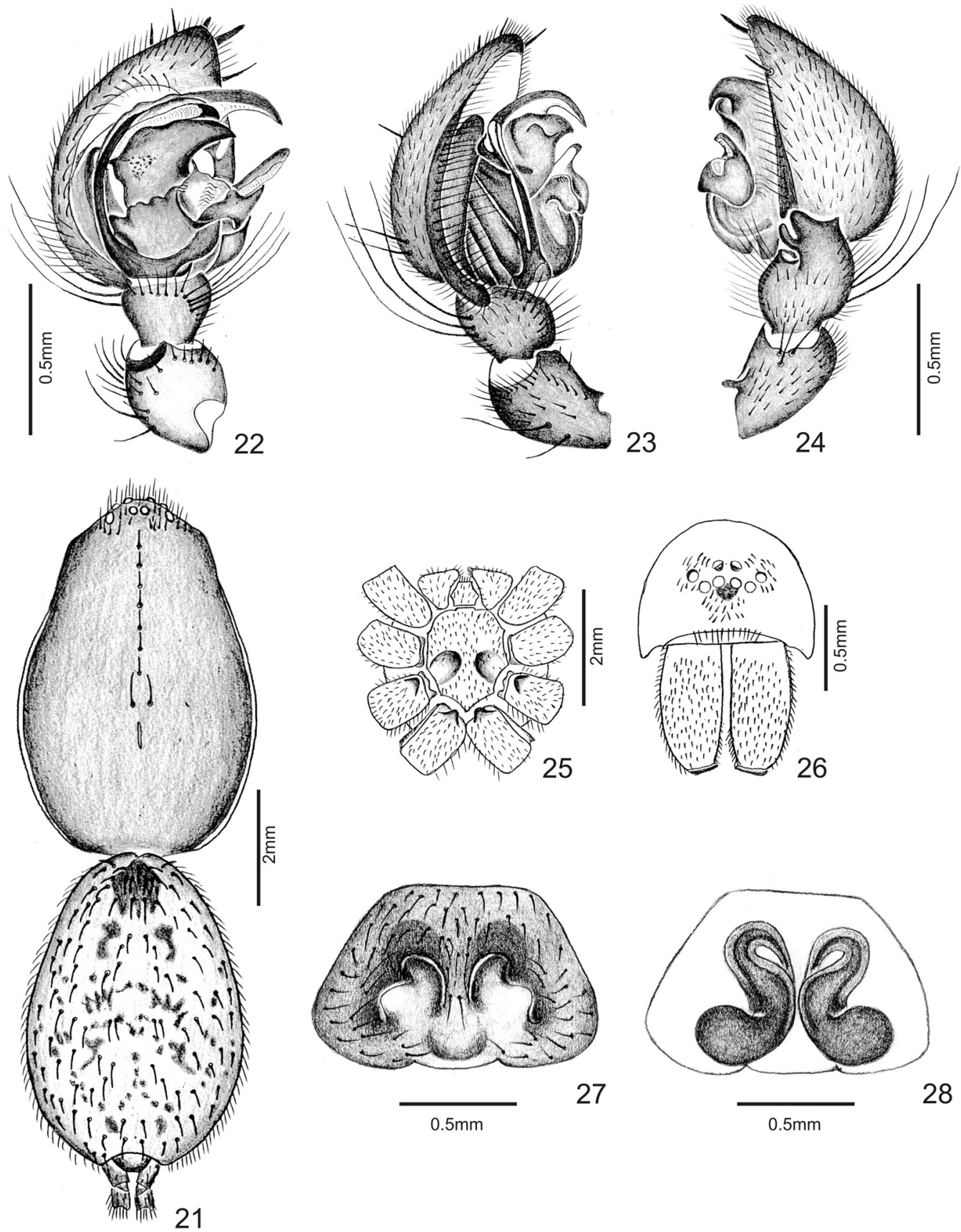

Figures 21-28. Cybaeodamus taim sp. nov.: 21, male body; 22-24, male palpus: 22, ventral view; 23, prolateral view; 24, retrolateral view; 25, cephalotorax, ventral view; 26, carapace and chelicerae; 27,28 , female epigynum: 27 , ventral view; 28 , dorsal view, cleared.

Other material examined. BRAZIL. Rio Grande do Sul: Viamão (Parque Estadual de Itapuã), 820', 189, 29.VIII.200308.X.2003, A. C. K. Ferreira col. (MCTP 16381-17062); ARGENTINA. Misiones: Zehura (Estr. Partridge), O’, 07.VII, without collector (MACN 10754). Mendoza: Luján de Cuyo (Puente del Inca), 30', 23.III.1976, 16.III.1977, A. Roig col. (MACN 10752, 10753). Río Negro: 25 de Mayo (Ñe Luan), 39, I.1975, E. Maury col. (MACN 10749). Neuquén: Bariloche,, , II.1954, M. E. Galiano col. (MACN 5421). Chubut: Gastre, ${ }^{\circ}$, XI.1976, D Nevez col. (MACN 10750); Chucas (Parque Nacional los Alerces), ㅇ, XI.1982, M. Ramirez col. (MACN 10751). Santa Cruz: Lago Argentino (El Calafate),, , II.1963, E. Maury col. (MACN 10748); URUGUAY. Canelones: Marindia, 50, $0^{*}$, 02.II.199602.XII.1998, Costa col. (FCE-AR 2434-2436).

\section{Cybaeodamus brescoviti sp. nov.}

(Figs. 37-41, 68)

Types. Holotype ơ', BRAZIL, Maranhão: Barreirinhas (Parque Nacional dos Lençóis Maranhenses), 13-17.X.2001, A. D. Brescovit col. (IBSP 33995). Paratypes: $ᄋ$ (IBSP 33994), $40^{7}$ (IBSP 33990, 33991, 33992, 33996); $20^{7}$ (MCTP 19989), same data as holotype.

Etymology. The specific name is a noun in apposition to the genus name and is a patronymic in honor to the Brazilian arachnologist Dr. Antonio Domingos Brescovit. 

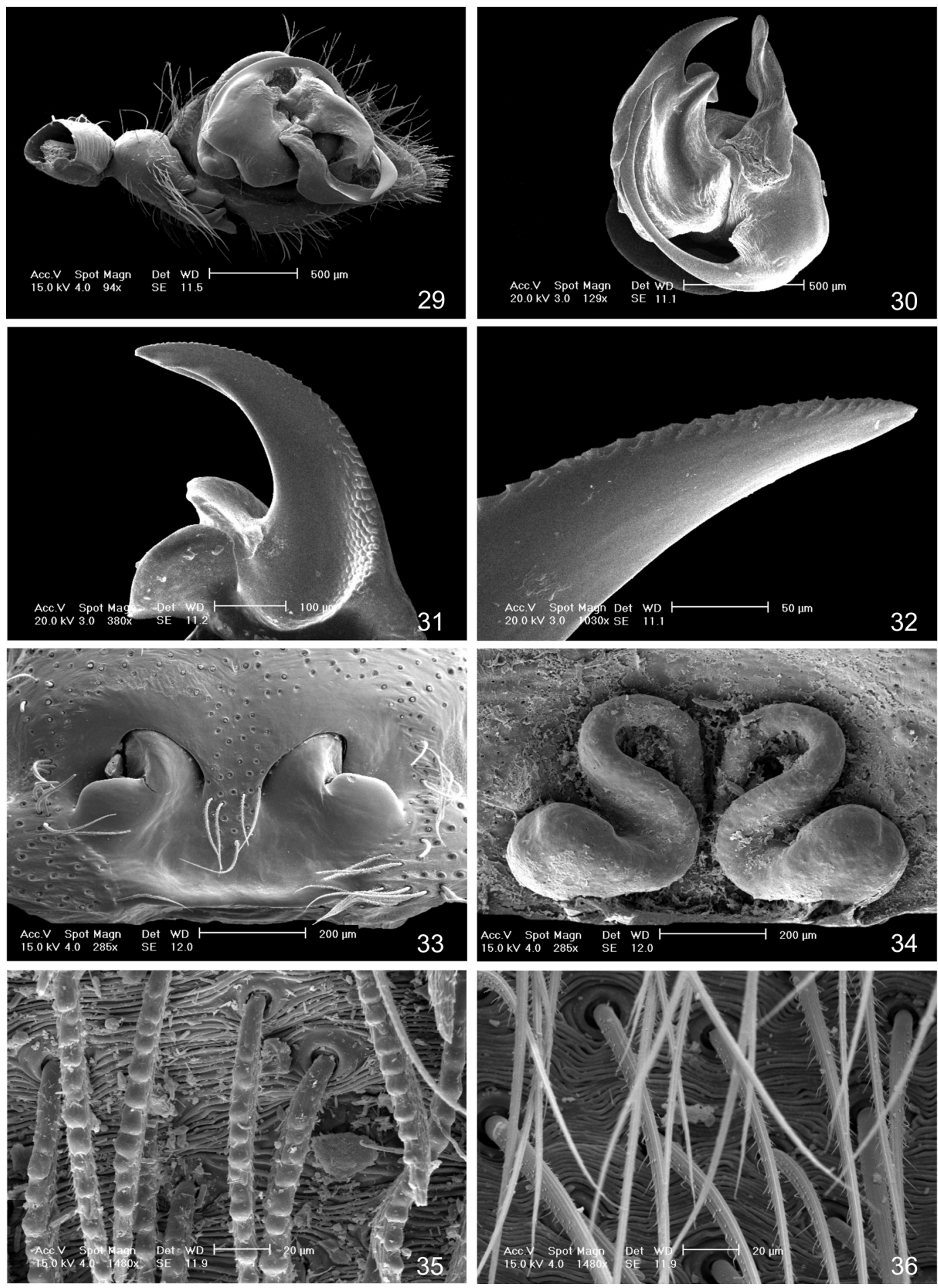

Figures 29-36. Cybaeodamus taim sp. nov.: 29, male palpus, ventral; 30, palpus, detail; 31, tegular distal apophisis, detail; 32, apex of tegular distal apophysis, detail; 33, 34, epigynum: 33, ventral view; 34, dorsal view; 35, patch on the ventral face of male abdomen; 36, patch on the ventral face of female abdomen.

Diagnosis. Males of C. brescoviti sp. nov. are similar to the those of $C$. enigmaticus by having similar retrolateral tibial apophysis but differ by this being wider ending into two blunt eminences and by having a short tegular lateral apophysis (Figs. 37-39). Females differs from the ones of the other species of the genus by the presence of a median cordiform plate on the epigynum covering the fecundation openings and by the large spheroid spermatecae (Figs. 40, 41).

Description. Male (holotype). Total length 6.75 . Carapace 3.23 long, 2.07 wide, 2.66 height. Sternum 1.56 long, 1.30 wide. Carapace yellowish fulvous, spotted with black, glabrous with a single median longitudinal row of bristles and some on the ocular area. Fovea longitudinal, 
narrow. Chelicerae light reddish chestnut, densely covered with black bristles. Endites triangular, yellow, whitish on top, mesal apical scopula black. On the median basal third there is a glabrous area. Labium fulvous, bristly. Sternum with dark margins, chestnut, central portion yellowish fulvous, scutiform, laterally carved on the level of coxae, convex, densely coated with black setae. Ocular area with four strong black setae. Anterior and posterior eyes row procurved, posterior more procurved. Leg formula 4.1.3.2. Measurements I/II/III/IV: femur 1.97/1.85/1.97/2.17; patella 0.84/0.80/0.80/0.93; tibia 1.60/1.30/1.03/1.35; metatarsus 1.46/1.32/1.38/1.82; tarsus 0.84/0.84/0.96/1.13. Total 6.71/ 6.11/6.14/7.14. Coxae of legs I and II fulvous, femura greenish black, the remaining of articles yellow. Coxae of legs III and IV dark fulvous, femura with the basal third whitish. Tarsi spiny. Abdomen 3.10 long, 2.04 wide, 2.14 height. Color of dorsum white guanine with a median longitudinal dark chestnut spot. Venter whitish with some spots near the epigastric furrow. Median longitudinal area covered with curved black spatulated setae. Spinnerets with base and top white. Palpus with a distal curved tegular apophysis (Fig. 37).

Female (paratype, IBSP 33994). Total length 6.08. Carapace elliptic, high, narrowed in front, 3.23 long, 1.95 wide, 1.15 height. Sternum 1.50 long, 1.10 wide. Carapace with a median elliptic yellow spot that extend from the PME to the posterior margin of fovea, remaining of carapace shadowed with black. Thoracic furrow darker. Tegument slightly setaceous with a median longitudinal row of more conspicuous setae. Chelicerae light chestnut, densely revested with strong black setae. Endites, triangular, convergent, yellow revested with long strong black setae. Labium chestnut, bristly. Sternum light chestnut very convex, densely setaceous. Clypeus and ocular area very setaceous. Leg formula 4,1,3,2. Measurements I/II/III/IV: femur 1.86/1.64/1.60/1.90; patella 0.92/0.86/0.84/0.90; tibia 1.34/1.10/0.80/1.30; metatarsi 1.10/ 1.00/1.26/1.74; tarsi 0.70/0.64/0.76/0.98. Total 5.92/5.24/ 5.26/6.82. Legs fulvous with macrosetae. Abdomen 3.75 long, 3.15 wide, 3.25 height. Color of dorsum cream yellowish suffused with black on the median longitudinal portion. Venter with an elongate spot on each side, on the posterior third, same color of dorsum. Lateral face with a longitudinal chestnut stripe and three more diagonal, of same color. Spinnerets yellowish, bristly. Colulus formed by two tuffs of setae. Epigynum with a cordiform median plate, spermatecae spheroid (Figs. 40, 41). Variation. Males (6). Total length: 5.30-6.75; carapace: 2.69-3.23; femur I: 1.84-2.13.

Distribution. Northeast of Brazil (Maranhão).

\section{Cybaeodamus enigmaticus (Mello Leitão, 1939)}

$$
\text { (Figs. 42-47, 68) }
$$

Rubrius enigmaticus Mello-Leitão, 1939:57, figs. 23-25 (described the male in Agelenidae); Rотн, 1967:343 (transferred to Zodariidae incertae sedis).

Hyltoniella birabeni Mello-Leitão, 1940:29, figs. 31,32, pl. I, fig. 3 (described the male); JocQué, 1991:50 (Syn.).

Cybaeodamus enigmaticus; JoCQué, 1991:53, figs. 88-93 (only male); Platnick, 2007.

Type. Holotype $\sigma^{\top}$ (examined), ARGENTINA, Camarones, Patagonia, A. Masarey col. (Naturhistorisches Museum Basel). Female unknown (see discussion).
Diagnosis. Male palpus with elongated tegular distal apophysis, lateral tegular apophysis wide and elongated distally (Figs. 42-45) and a patch of setae on ventral view of abdomen (Figs. 46, 47).

Description. See Mello-Leitão (1939).

Other examined material. ARGENTINA. Buenos Aires: Villarino (Montes de Oca), Ơ, 24.II.1982, E. Maury col. (MACN 10746). Catamarca: Andalgalá, (Andalgalá), Ơ, 19.X.1972, Endergs col. (MACN 10747).

Distribution. Known only for Argentina.

Discussion. JocQué (1991: Fig. 93) presented a drawing of the dorsal view of the epigynum (Fig. 93) but we believe it does not belong to $C$. enigmaticus.

\section{Cybaeodamus lycosoides (Nicolet, 1849) \\ (Figs. 48, 49, 68)}

Drassus lycosoides NiCOLET, 1849:453 (described female). Storena lycosoides Simon, 1889:218.

Cybaeodamus lycosoides JocQuÉ, 1991:50 (transferred from Storena); Platnick, 2007.

Type. Holotype $\bigcirc$ (examined), CHILE. No locality, date or collector designation (MNHN 9954). The vial contains a label with the following data: "Museu Paris AR9954; Storena lycosoides Nic. (Drassus), Chili, E. Simon dét."

Diagnosis. Spermatecae spherical, appart from each other by more than their diameter (Figs. 48, 49).

Description. See Nicolet (1849).

Distribution. Know only from the type locality.

Discussion. JocQué (1991), affirms that the female holotype is a subadult specimen. The examined holotype is an adult what can be confirmed by the here presented figures of ventral and dorsal views of the epigynum (Figs. 48, 49).

\section{Cybaeodamus ornatus Mello-Leitão, 1938 (Figs. 50-59, 68)}

Cybaeodamus ornatus Mello-Leitão, 1938:93, figs. 4, 5 (described male and female in Agelenidae); Mello-Leitão, 1941:119, pl. 3, fig. 11 (female); Rотн, 1965:290 (transferred to Zodariidae); JoCQUÉ, 1991:50, figs. 82-87.

Types. Lectotype $\sigma^{7}$ (examined), ARGENTINA. Buenos Aires: La Plata (Río Santiago) (MLP 14033). Paralectotype o (examined), La Plata (Río Santiago) (MLP 14034). Paratype $\sigma^{7}$ (not examined), La Plata (Río Santiago), Max Birabén col. (Museu Nacional Rio de Janeiro 58045)

Diagnosis. Male palpus with short tegular distal apophysis; lateral tegular apophysis distally pointed, embolus with wide base (Figs. 50, 51, 54). Female can be recognized by having the spermatecae appart from each other more than their diameter and by the long sinuose copulatory ducts with basal portion appart from each other around the spermatecae diameter (Figs. 52, 53, 5557 ) and a patch of setae on the ventral face of abdomen (Fig. 59). Males have a patch of granulose setae on the ventral face of abdomen (Fig. 58).

Description. See Mello-Leitão (1938).

Other examined material. PERU. Puno: Entre Puno y Pancarcolla, ơ, ㅇ, 16.X.1983, E. Maury col. (MACN 10729). ARGENTINA. Salta: Rosario de Lerna (El Alizal), 2ㅇ, 20.I.1981, A. Roig col. (MACN 10725). Santiago del Estero: Moreno 
(Mercedes, 10 km Este Amaná), ๆ, 07.VIII.1995, D. Vezzani col. (MACN 10730); Moreno (Mercedes), \&, I.1996, D. Vezzani col. (MACN 10727). Buenos Aires: Bahia Blanca,, , II.1942, F. Morrôs col. (MACN 10723); Bahia Blanca (Quinta La China, 25 Km Sierra de la Ventana), 9우 20.III.1983, E. Maury col. (MACN 10728); Patagones (Bahia San Blas), 20',, , no date, C. Daguerre col. (MACN 10731); Tandil, O', V.1967, E. Maury col. (MACN 10732); Balcarce (Sierra la Barrosa), 29, 19-21.VII.1974, E. Maury col. (MACN 10738); Patagones (Carmen de Patagones, Rio Azi), , II.1975, E. Maury col. (MACN 10724); Patagones (Carmen de Patagones), on,
IV.1971, Aquilera col. (MACN 10735). La Pampa: Liuhel Calel, 29, 10.XI.1969, 22.I.1985, E. Maury col. (MACN 10726, 10734). Rio Negro: General Roca (General Roca-Balsa), + , I.1962, B. Bachmann col. (MACN 5468). La Rioja: Independencia (Patquia), O', X.1968, M. E. Galiano col. (MACN 10740); Arauco (Ascha Almogasta), 50", 29, 1941, 1943, X.1947, J. C. Freye col. (MACN 2118, 2178, 10723, 10743, 10745). San Juan: Valle Fertil, 20, $\odot$, XI.1970, Viana col. (MACN 10733). Chubut: Biedma (Puerto Madryn),, , 09.III.1969, Gazztonyi col. (MACN 10741); Florendino Ameghino (Bahia Aredondu), 2ᄋ, I.1976, E. Maury col. (MACN 10739).
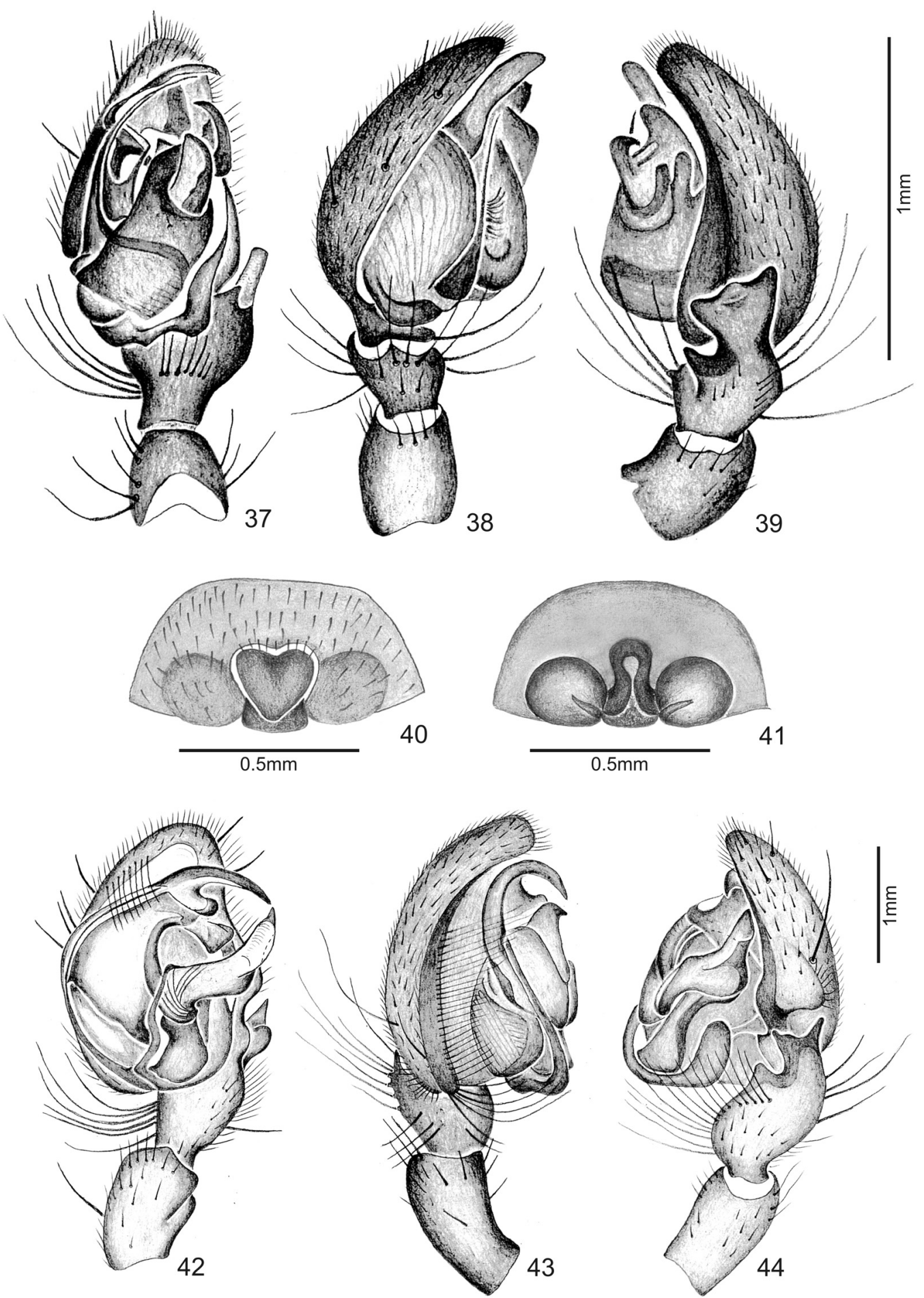

Figures 37-44. Cybaeodamus brescoviti sp. nov.: 37-39, male palpus: 37, ventral view; 38, prolateral view; 39, retrolateral view; 40, 41, epigynum: 40, ventral view; 41, dorsal view; Cybaeodamus enigmaticus (Mello Leitão, 1939): 42-44, male palpus: 42, ventral view; 43, prolateral view; 44 , retrolateral view. 
Distribution. Argentina (Salta, Santiago del Estero, Buenos Aires, La Pampa, Rio Negro, La Rioja, San Juan and Chubut), Peru (Puno) and Uruguay (JOCQUÉ, 1991:52).

\section{Cybaeodamus tocantins sp. nov. (Figs. 60-67, 68)}

Types. Holotype ơ, BRAZIL, Tocantins: Palmas, X.2001, D. Pavan col. (MZSP 21151). Paratypes: 190', + , Palmas, II.2001X.2001, D. Pavan col. (MZSP 21152-21156); Mato Grosso: ơ, Chapada dos Guimarães, 20-28.IX.2000, C. Strüssmann col. (MCTP 11567).

Etymology. The specific name is a noun in apposition to the genus name and refers to the type locality.

Diagnosis. Males of $C$. tocantins sp. nov. differ from the ones of the other species of the genus by the presence of a boss on leg IV (Fig. 62), tibial apophysis elongate and pointed distally on retrolateral view (Fig. 65 ) and concave on prolateral side (Fig. 63). Females differ from the ones of the other species of the genus by the shape of the epigynum, with a median longitudinal atrium (Fig. 66). Spermatecae reniform (Fig. 67).

Description. Male (holotype). Total lenght 4.80. Carapace as in the other species, 2.56 long, 1.71 wide, 0.60 height. Sternum 1.30 long, 1.00 wide. Carapace (Fig. 60) yellow, lateral and inferior margins dark chestnut. Fovea longitudinal, narrow, chestnut very dark. Chelicerae chestnut, bristly. Endites whitish yellow, bristly. Labium chestnut, bristly. Sternum yellow, bordered with light chestnut, apex dark chestnut, with long strong erected bristles. Ocular area bristly with a median longitudinal row of macrosetae. Leg formula 4,1,2,3. Measurements I/II/III/IV: femur 1.66/1.52/1.60/1.80; patella 0.66/0.66/0.60/0.74; tibia 1.12/0.96/0.80/1.14; metatarsus 1.02/0.96/1.02/1.40; tarsus 0.78/0.76/0.78/0.96. Total 5.24/ 4.86/4.80/6.04. Legs femura dark chestnut, patellae fulvous, tibiae yellow with basal third light chestnut, metatarsi and tarsi yellow. Legs I and II with a dorsal basal macroseta on tibia. Legs III and IV with many spines. Coxae III with a ventral apical unconspicuous tubercle (Fig. 61), femur with a ventral basal tubercle (Fig. 62), coxae IV with an assemblage of tick setae on the inner margin. Abdomen 2.23 long, 1.48 wide, 1.60 height. Color of dorsum white, reticulated of guanine with a dark chestnut spot from which start three pairs of dorsum lateral stripes of same color. Venter with the epigastric area light fulvous, the remaining yellowish with some guanine spots. Median central area with dark chestnut setae. Lateral with a longitudinal light chestnut stripe. Spinnerets light chestnut. Palpus with tibial apophysis pointed on the distal portion, on retrolateral view (Fig. 65) and concave on prolateral side (Fig. 63), tegulum (Fig. 64) globose on retrolateral view (Fig. 65).

Female (paratype, MZSP 21152). Total length 5.30. Carapace 2.46 long, 1.48 wide, 0.88 height. Sternum 1.14 long, 0.90 wide. Carapace light chestnut with a large central longitudinal yellowish spot. Fovea longitudinal, dark chestnut. Chelicerae dark chestnut, densely coated with setae. Endites yellow, bristly. Labium chestnut bristly. Sternum light chestnut, oval, bristly. Ocular area blackish, bristly with a median longitudinal row of
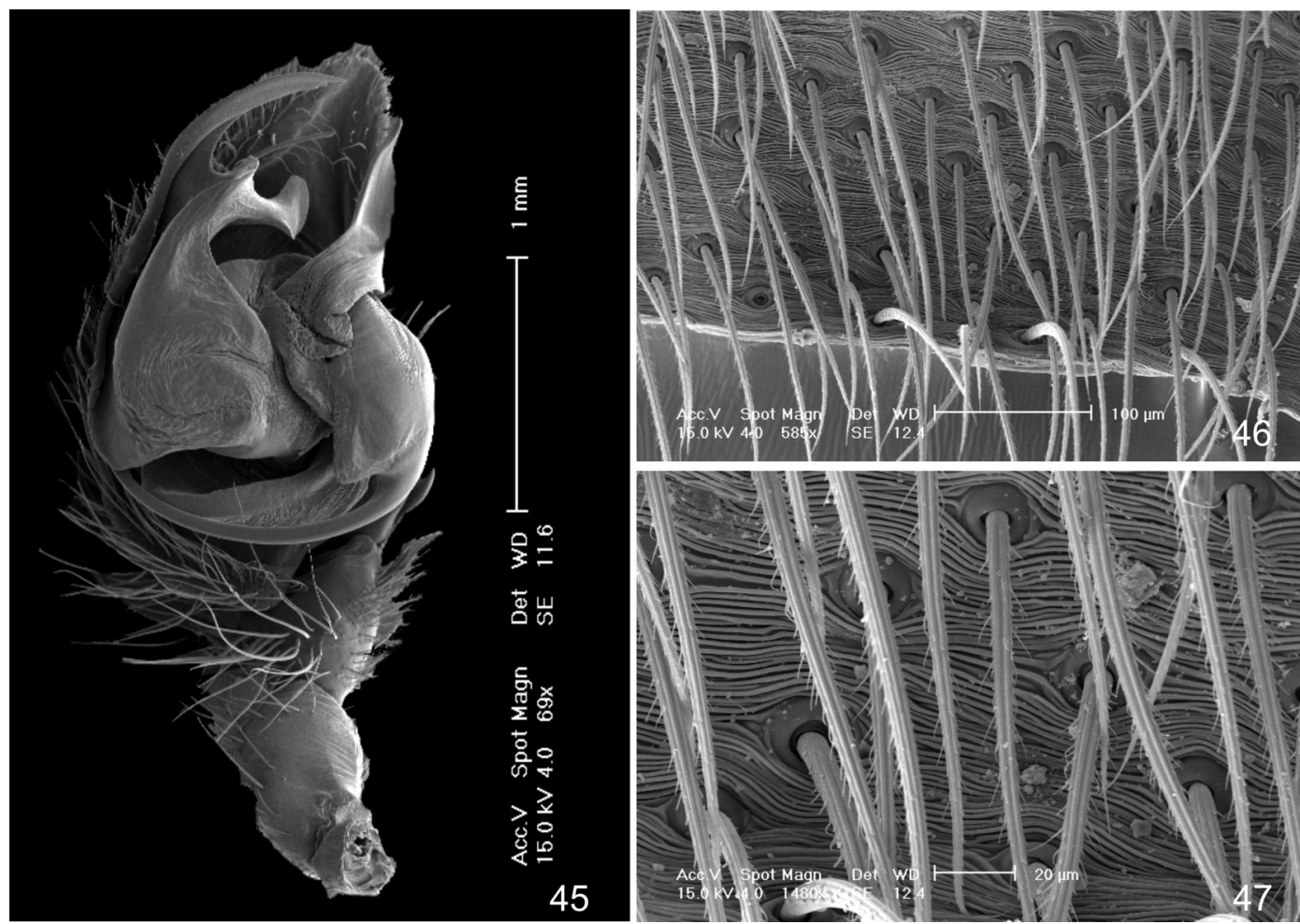

Figures 45-47. Cybaeodamus enigmaticus (Mello Leitão, 1939): 45, palpus, ventral view; 46, patch of the ventral face of the male abdomen; 47, idem, detail. 
macrosetae. Leg formula 4,1,3,2. Measurements I/II/III/ IV: femur $1.34 / 1.22 / 1.24 / 1.50$; patella $0.64 / 0.64 / 0.60 / 0.68$; tibia 0.96/0.76/0.60/1.00; metatarsus 0.84/0.80/0.94/1.50; tarsus 0.64/0.60/0.68/0.80. Total 4.42/4.02/4.06/5.48. Legs I, II and III with femura yellow on the ectal and ventral faces shadowed with gray. Remaining articles fulvous. Legs IV with femura ectal end ventral faces whitish yellow, remaining articles fulvous. Legs III and IV very spinous. Abdomen 2.63 long, 1.81 wide, 1.48 height. Dorsum yellowish, shadowed with black. Laterals and venter yellow, epigynum dark chestnut. Spinnerets light fulvous. Epigynum with median longitudinal atrium (Fig. 66).

Variation. Males (10). Total length: 4.00-5.00; carapace: $2.00-2.69$.
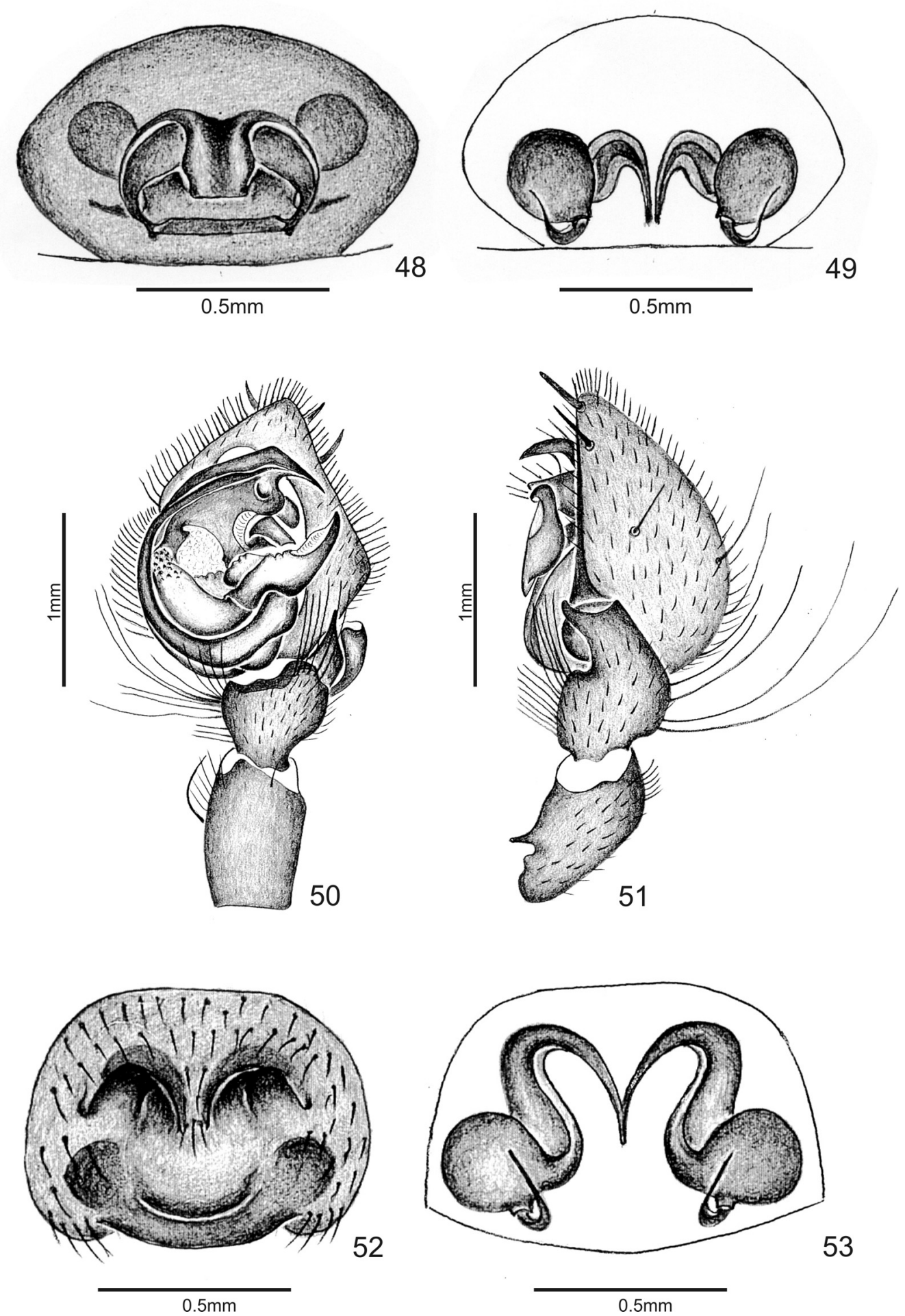

Figures 48-53. Cybaeodamus lycosoides (Nicolet, 1849): 48, 49, epigynum: 48, ventral view; 49, dorsal view; Cybaeodamus ornatus Mello-Leitão, 1938: 50, 51, male palpus: 50, ventral view; 51, retrolateral view; 52, 53, epigynum: 52, ventral view; 53, dorsal view. 
Distribution. North and Central west region of Brazil (Tocantins and Mato Grosso).

Other material examined. BRAZIL. Tocantins: Palmas, 20, X.2001, D. Pavan col. (MCTP 19987). Mato Grosso: Chapada dos Guimarães, O’, 20-28.IX.2001, C. Strüssmann col. (MCTP 19988).

\section{Cybaeodamus nigrovittatus Mello-Leitão, 1941, species inquirenda}

Cybaeodamus nigrovittatus Mello-LeItão, 1941:118, pl. 4, fig. 12.

Type. Holotype $q$ (examined, immature), ARGENTINA, Catamarca, Belén, II-III.1939, M. Birabén col. (MLP 14658).

\section{Cybaeodamus pallidus (Mello-Leitão, 1943), species inquirenda}

Valcheta pallida Mello-Leitão, 1943:106.

Type. Holotype + (probably lost, not examined), ARGENTINA, Mendoza, Los Molles.
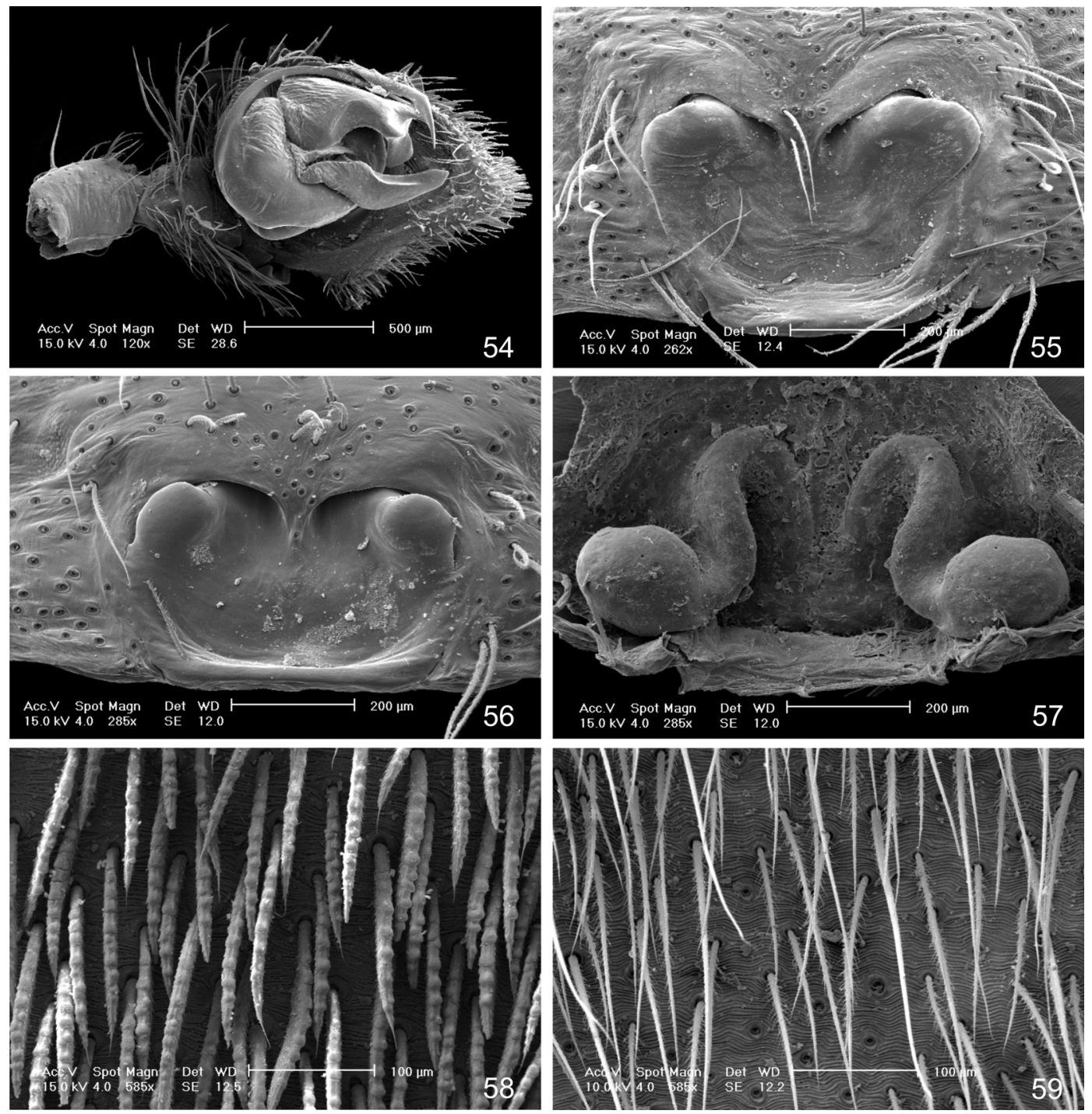

Figures 54-59. Cybaeodamus ornatus Mello-Leitão, 1938: 54, palpus, ventral view; 55-57, epigynum: 55, 56, ventral view; 57, dorsal view; 58, patch of the ventral face of male abdomen; 59, patch of the ventral face of female abdomen. 

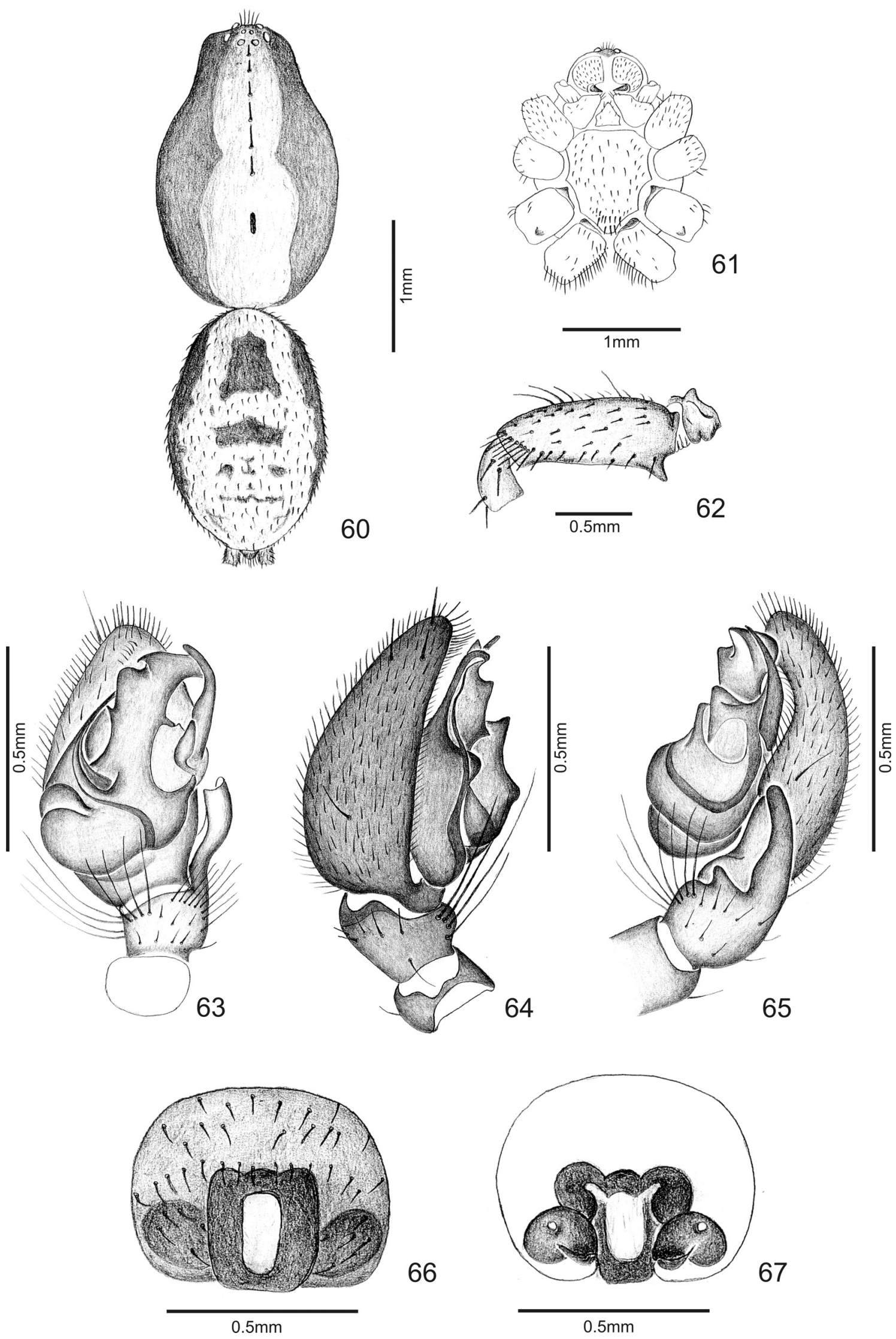

Figures 60-67. Cybaeodamus tocantins sp. nov.: 60, male, dorsal view; 61, male carapace, ventral view; 62, femur of leg III; 63-65, male palpus; 63, ventral view; 64, prolateral view; 65, retrolateral view; 66, 67, epigynum: 66, ventral view; 67, dorsal view. 


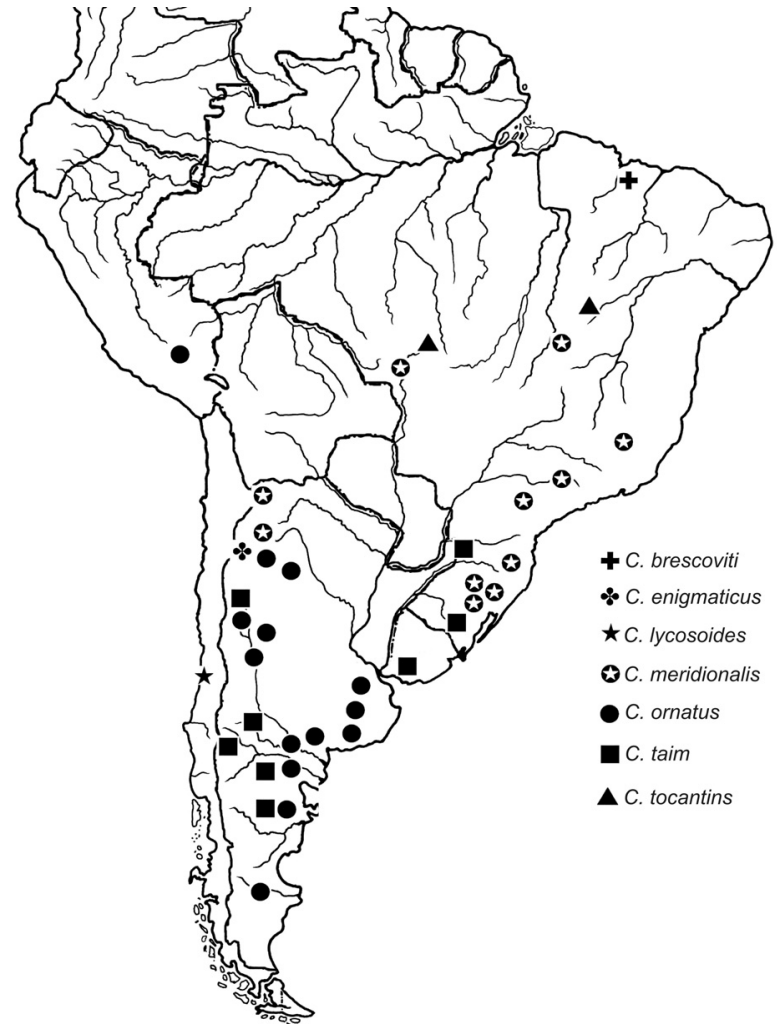

Figure 68. Distribution of Cybaeodamus species in South America.

Acknowledgments. We are grateful to Mónica Tassara of the Museo de La Plata for the attention; the Direction of Museu de Ciências Naturais da Fundação Zoobotânica do Rio Grande do Sul by permitting the third author to develop part of this work in its dependences; for anonymous reviewers for their valuable comments on the manuscript; to the staff of Centro de Miscroscopia e Microanálises da PUCRS, for the help in obtaining the SEM images; to "Conselho Nacional de Desenvolvimento Científico e
Tecnológico" for the Grant (CNPq 140586/2007-5) gave to E. N L. Rodrigues; to the curators of the collections mentioned for the loan of material and to Estevam L. C. da Silva for the help on preparing the final art of the illustrations.

\section{REFERENCES}

Jocoué, R. 1991. A generic revision of the spider family Zodariidae (Araneae). Bulletin of the American Museum of Natural History 201:1-160.

Lehtinen, P. T. 1967. Classification of the cribellate spiders and some allied families, with notes on the evolution of the suborder Araneomorpha. Annales Zoologici Fennici 4:199-468.

Mello-Leitão, C. F. 1938. Algunas arañas nuevas de la Argentina. Revista del Museu de La Plata (N.S., Zool.) 1:89-118. 1939. Araignées américaines du Musee d'histoire naturelle de Bâle. Revue suisse Zoology 46:43-93.

1940. Arañas de la provincia de Buenos Aires y de las gobernaciones de La Pampa, Neuquén, Río Negro y Chubut. Revista del Museu de La Plata (N.S., Zool.) 2:3-62.

. 1941. Las arañas de Córdoba, La Rioja, Catamarca, Tucumán, Salta y Jujuy colectadas por los Profesores Birabén. Revista del Museu de La Plata (N.S., Zool.) 2:99-198.

1943. Arañas nuevas de Mendoza, La Rioja y Córdoba colectadas por el Professor Max Birabén. Revista del Museu de La Plata (N.S., Zool.) 3:101-121.

Nicolet, A. C. 1849 . Aracnidos. In: GAY, C. ed. Historia física y política de Chile. Zoología 3:319-543.

Platnick, N. I. 2007. The world spider catalog, version 7.5 American Museum of Natural History. Avaliable at: <http:// research.amnh.org/entomology/spiders/catalog/index.html>. Accessed on: 16.05.2007.

Rотн, V. D. 1965. Genera erroneously placed in the spider families Agelenidae and Pisauridae (Araneida: Arachnida). Annals of the Entomological Society of America 58:289-292.

1967. A review of the South American spiders of the family Agelenidae (Arachnida, Araneae). Bulletin of the American Museum of Natural History 134:297-346.

Simon, E. 1889. Etudes arachnologiques. 21e Mémoire. XXX Descriptions de quelques arachnides du Chili et remarques synonymiques sur quelques unes des espèces décrites par Nicolet. Annales de la Société Entomologique de France, ser. 6 (8):217-222 